\title{
Necrosis of osteosarcoma cells induces the production and release of high-mobility group box 1 protein
}

\author{
JIYU YANG ${ }^{*}$, ZHIQIANG MA* , YANLONG WANG, ZENGKUN WANG, YOUWEI TIAN, \\ YINGCHAO DU, WEI BIAN, YONGFU DUAN and JIANYU LIU \\ Department of Orthopedic Surgery, The Second Hospital of Harbin Medical University, \\ Harbin, Heilongjiang 150086, P.R. China
}

Received July 24, 2016; Accepted May 5, 2017

DOI: $10.3892 /$ etm.2017.5415

\begin{abstract}
Osteosarcoma is among the commonly observed malignancies worldwide. High-mobility group box 1 protein (HMGB1) is a highly conserved protein and is involved in the progression of various types of human cancer. The aim of the present study was to explore whether the level of HMGB1 was involved in the necrosis of osteosarcoma cells. Doxorubicin (DXR), as an inducer of necrosis, was administered to human osteosarcoma cell lines (MG63, Saos-2 and U2OS), and the results indicated that $0.5 \mu \mathrm{g} / \mathrm{ml}$ DXR significantly induced the necrosis of MG63 cells ( $\mathrm{P}<0.01)$, while 0.5 and $1.0 \mu \mathrm{g} / \mathrm{ml} \mathrm{DXR}$ suppressed the viability of MG63 and U2OS cells $(\mathrm{P}<0.05)$, relative to untreated controls. Additionally, treatment with DXR was observed by western blot analysis to markedly increase the expression levels of HMGB1 in MG63 cells, and to significantly increase the levels of secreted HMGB1 in the supernatants of MG63 and U2OS cells $(\mathrm{P}<0.01)$. In conclusion, cell necrosis increased the level of HMGB1 in osteosarcoma cells, as well as the level of secreted HMGB1 in cell supernatants. Therefore, HMGB1 may be a potential target in molecular therapy for patients with osteosarcoma.
\end{abstract}

\section{Introduction}

Osteosarcoma is a malignant primary tumor of the bone, which can produce a bone-like tumor comprised of bone connective tissues, including collagen, elastic fibers and ground substances $(1,2)$. It is the most common primary tumor of malignant bone tumors (1). Osteosarcoma may occur at any age, though has been most frequently observed in adolescents

Correspondence to: Dr Jianyu Liu, Department of Orthopedic Surgery, The Second Hospital of Harbin Medical University, 246 Xuefu Road, Harbin, Heilongjiang 150086, P.R. China

E-mail: liujianyured@163.com

${ }^{*}$ Contributed equally

Key words: high-mobility group box 1 protein, osteosarcoma, necrosis, doxorubicin
$<25$ years old, and is considered to occur more often in males than females (3). Due to its prevalence, it is important to enhance the clinical efficacy of treatment for osteosarcoma (4). Upon diagnosis of osteosarcoma, in addition to surgery, chemotherapy is crucial for more effective treatment $(5,6)$.

Previous studies have reported that cell necrosis was associated with chemotherapy, rather than occurring as a spontaneous event, in osteosarcoma patients upon receipt of preoperative chemotherapy $(7,8)$. The histological response to preoperative chemotherapy, particularly tissue necrosis, has been implicated as an important clinical predictor of the outcome of operative treatment for osteosarcoma $(9,10)$; in patients with a necrosis rate $>70 \%$, a significantly higher rate of disease-free survival (DFS) was observed when compared with those exhibiting a necrosis rate $<70 \%$ (9). However, Li et al identified no survival advantage for a tumor necrosis rate of $90 \%$ (11). Nevertheless, it has been suggested that further studies with more patients will aid to elucidate the predictive value of the necrosis rate at a cutoff of $70 \%$ (11). More recently, Kato et al (12) identified that anti-tumor necrosis factor (TNF) therapy inhibited metastasis to the lungs in an osteosarcoma cell line (143B), and thus concluded that TNF- $\alpha$ inhibition may be a preventive therapeutic strategy for the pulmonary metastasis of osteosarcoma. Therefore, it is necessary to clarify the association between necrosis and the progression and/or metastasis of osteosarcoma.

In osteosarcoma therapy, metastasis and chemoresistance of malignant cells contribute to treatment failure $(9,13)$. Previous studies have reported that high-mobility group box 1 protein (HMGB1) was a critical factor in the development of chemoresistance (14-16), and notably, that it promoted drug resistance in osteosarcoma, thus suggesting a novel target for improving osteosarcoma therapy (15,17-19). Recently, Meng et al (20) observed that the tumorigenesis, invasion and metastasis of osteosarcoma was associated with overexpression of HMGB1, which may thus be a potential target for treatment (20). However, to the best of our knowledge, it has not been clarified whether HMGB1 is involved in cell necrosis during the development and progression of osteosarcomas. Therefore, the present study investigated the potential molecular mechanisms underlying cell necrosis and the levels of HMGB1 in osteosarcoma, with the aim of providing novel insights to improve the treatment of human osteosarcomas. 


\section{Materials and methods}

Cell lines and agents. The human osteosarcoma cell lines MG63, Saos-2 and U2OS were purchased from the American Type Culture Collection (Manassas, VA, USA). Human skeletal muscle cells (HSkMCs), as a normal control cell line, were purchased from Tongpai Biotechnology Co., Ltd. (Shanghai, China). Cells were cultured in Dulbecco's modified Eagle's medium (Sigma-Aldrich; Merck KGaA, Darmstadt, Germany) containing 10\% fetal bovine serum (Sigma-Aldrich; Merck $\mathrm{KGaA}$ ) and penicillin-streptomycin under $5 \% \mathrm{CO}_{2}$ at $37^{\circ} \mathrm{C}$ for $48 \mathrm{~h}$. Doxorubicin (DXR; cat. no. D1515) and MTT (cat. no. M2003) were obtained from Sigma-Aldrich (Merck $\mathrm{KGaA})$.

Fluorescence-activated cell sorting (FACS) assay. Annexin V-fluorescein isothiocyanate (FITC)/propidium iodide (PI) dual staining was used for a cell apoptosis assay according to the manufacturer's protocols (Beijing Solarbio Science \& Technology Co., Ltd., Beijing, China). Briefly, MG63 cells were treated with or without $0.5 \mu \mathrm{g} / \mathrm{ml}$ of DXR for $48 \mathrm{~h}$. The untreated MG63 were used as negative control cells. The human osteosarcoma cancer cells $\left(2 \times 10^{6}\right.$ cells/well $)$ were washed twice in cold PBS and fixed in $4 \%$ paraformaldehyde for $30 \mathrm{~min}$ at room temperature. The cells were then washed twice and RNase A (Sigma-Aldrich; Merck KGaA) was added to a final concentration of $100 \mathrm{ng} / \mathrm{ml}$. Annexin V-FITC $(0.1 \mu \mathrm{g} / \mu \mathrm{l})$ and PI $(0.05 \mu \mathrm{g} / \mu \mathrm{l})$ were added to the cells and the cells were incubated for $15 \mathrm{~min}$ on ice. Subsequently, the cells were analyzed by FCS Express 6 Flow Cytometry (FACScan; BD Biosciences, Franklin Lakes, NJ, USA).

MTT assay. An MTT assay was used to assess cell viability and proliferation. Briefly, MG63 and U2OS cells $\left(1 \times 10^{4}\right.$ cells/well) were plated in a 96 -well plate. The cells were treated with different concentrations of DXR $(0,0.1,0.5$ or $1.0 \mu \mathrm{g} / \mathrm{ml})$ for 24,48 or $72 \mathrm{~h}$. The control group $(0 \mu \mathrm{g} / \mathrm{ml}$ DXR) was treated with $0.1 \%$ dimethyl sulfoxide (DMSO). At each time point, $20 \mu \mathrm{l}$ MTT $(5 \mathrm{mg} / \mathrm{ml})$ was added and the cells were incubated for $4 \mathrm{~h}$ at $37^{\circ} \mathrm{C}$ prior to removal of the supernatant. DMSO (100 $\mu$ l; Sigma-Aldrich; Merck KGaA) was added to dissolve the formazan crystals and a spectrophotometer (DU-7400; Beckman Coulter, Inc., Brea, CA, USA) was used to measure the optical density (OD) values at a wavelength of $490 \mathrm{~nm}$. The inhibitory rate following DXR treatment was calculated with the following formula: Inhibitory rate $(\%)=[1-(\mathrm{OD}$ of the experimental samples/OD of the control)]x100. Maximal inhibitory concentration refers to the drug concentration that achieves the highest inhibition, indicating how much drug is needed to highly inhibit a biological process in pharmacological research (21).

Western blot analysis. Western blot assay was used to determine the relationship between DXR and HMGB1 in osteosarcoma cells. In one experiment, MG63 cells were treated with 0.1, 0.5 and $1.0 \mu \mathrm{g} / \mathrm{ml}$ of DXR for $24 \mathrm{~h}$. In the other, MG63 cells were treated with $0.5 \mu \mathrm{g} / \mathrm{ml}$ of DXR for 24,48 and $72 \mathrm{~h}$. Untreated cells $(0 \mu \mathrm{g} / \mathrm{ml}$ of DXR) were used as negative controls. Whole cell extracts were prepared and SDS-PAGE was used to separate them as previously described (22). The primary antibodies

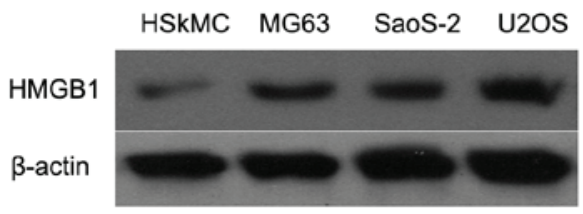

Figure 1. HMGB1 levels are increased in human osteosarcoma cell lines. The human osteosarcoma cell lines MG63, SaoS-2 and U2OS were plated in 48-well plates. The cells were cultured for $8 \mathrm{~h}$, and the expression of HMGB1 was measured by western blot analysis. HSkMCs were used as a normal control. HMGB1, high-mobility group protein 1; HSkMC, human skeletal muscle cell

used were mouse monoclonal anti-HMGB1 (cat. no. ab77302; Abcam, Cambridge, UK), mouse monoclonal anti- $\beta$-actin (C-2, cat. no. sc-8432; Santa Cruz Biotechnology, Inc., Dallas, TX, USA), while the secondary antibody was goat anti-mouse immunoglobulin G-horseradish peroxidase (cat. no. sc-2005; Santa Cruz Biotechnology, Inc.).). The protein bands were visualized with an enhanced chemiluminescence detection kit (Amersham; GE Healthcare, Chicago, IL, USA).

ELISA. A human HMGB1 ELISA kit (E-EL-H1554c; Wuhan Elabscience Biotechnology Co., Ltd., Wuhan, China) was used to determine the concentration of HMGB1 in the supernatants (following centrifugation at $1,500 \mathrm{x}$ g for $10 \mathrm{~min}$ at room temperature) of DXR-treated MG63 and U2OS cells after $48 \mathrm{~h}$. In the experiment, different concentrations of DXR were used; $1 / 2$ half maximal inhibitory concentration (IC50) and IC50 of each cell line. Here, the untreated MG63 cells or U2OS cells were used as negative controls. The experiment was performed according to the kit protocol using a Benchmark Microplate Reader (Bio-Rad Laboratories, Inc., Hercules, CA, USA). The samples were assayed in duplicate. Standard curves were used to calculate the concentrations of HMGB1 in the samples.

Statistical analysis. Statistical analysis was performed using SPSS 20.0 software (IBM Corp., Armonk, NY, USA). Multiple comparisons were performed by one-way analysis of variance followed by a Tukey's test. Pairwise comparisons were performed by two sets of independent samples t-tests. The data were depicted as the mean \pm standard deviation, and $\mathrm{P}<0.05$ was considered to indicate statistical significance.

\section{Results}

HMGB1 levels are increased in human osteosarcoma cell lines. To evaluate the role of HMGB1 in human osteosarcoma cells, western blot analysis was firstly used to determine the levels of HMGB1 in MG63, Saos-2 and U2OS cells, and in control HSkMCs. As depicted in Fig. 1, the levels of HMGB1 were markedly increased in the MG63, SaoS-2 and U2OS cells when compared with that in the HSkMCs. These data suggested that HMGB1 may act as an oncogene in the development of human osteosarcoma.

Treatment with DXR increases the necrotic rate of MG63 cells. It has been reported that large-scale cell necrosis may be induced by cancer thermotherapy (23). In the present study, the necrosis inducer DXR was administered to human 

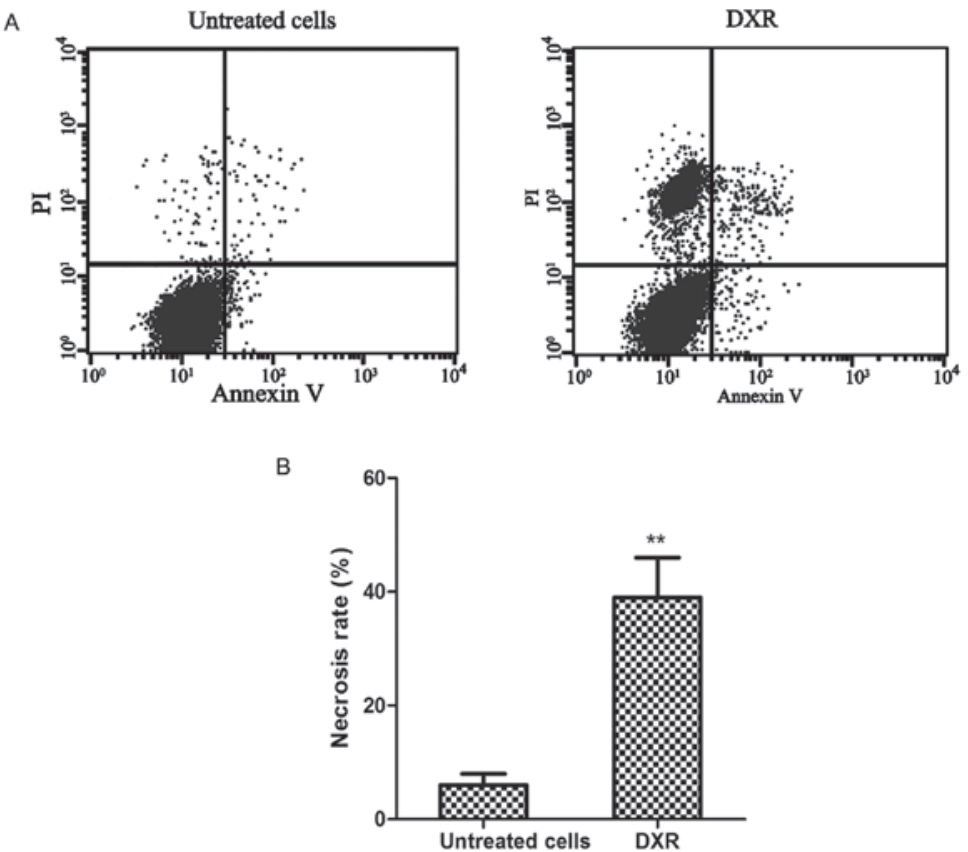

Figure 2. Treatment with DXR increases the necrotic rate of MG63 cells. (A) Fluorescence-activated cell sorting assay. Human osteosarcoma cancer MG63 cells were treated with or without $0.5 \mu \mathrm{g} / \mathrm{ml}$ of DXR for $48 \mathrm{~h}$. The rates of cell necrosis and apoptosis were determined by Annexin V-fluorescein isothiocyanate/PI staining. (B) The necrosis rates of the DXR-treated and untreated groups were depicted in a histogram. ${ }^{* *} \mathrm{P}<0.01$ vs. untreated cells. DXR, doxorubicin; PI, propidium iodide.

A

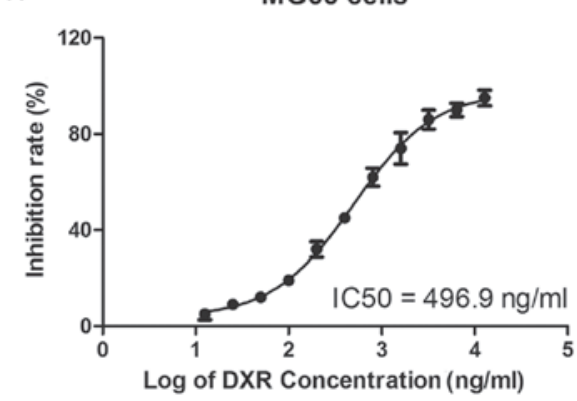

B

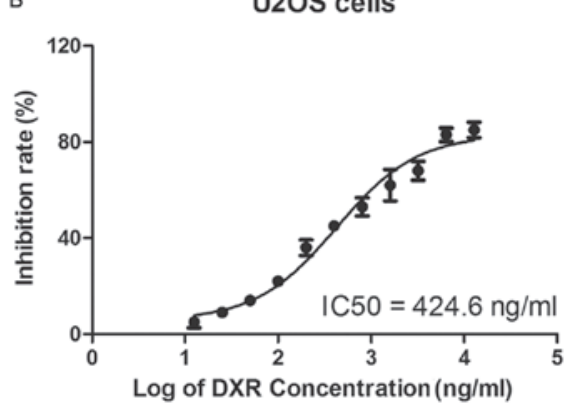

Figure 3. DXR suppresses the viability of human osteosarcoma cells. The human osteosarcoma cancer cell lines (A) MG63 and (B) U2OS were treated with increasing concentrations of DXR for $24 \mathrm{~h}$, and cell viability was determined by MTT assay. The inhibitory rate of DXR (\%) was calculated as follows: $\left(1-\mathrm{OD}_{450}\right.$ in the experimental group/OD 450 in the control group)x100. DXR, doxorubicin; OD, optical density; $\mathrm{IC}_{50}$, half maximal inhibitory concentration.

osteosarcoma cells, and the role of HMGB1 during the process of cell necrosis was investigated. The human osteosarcoma cancer MG63 cells were incubated with or without $0.5 \mu \mathrm{g} / \mathrm{ml} \mathrm{DXR}$ for $48 \mathrm{~h}$, and the rates of cell apoptosis and necrosis were assessed by Annexin V-FITC/PI staining of the DXR-treated and untreated groups (Fig. 2A). It was observed that DXR induced cell death in the osteosarcoma cells, which was identified to be mainly of the cell necrosis type by the markedly higher proportion of PI-positive (necrotic) cells than Annexin V-positive/PI-negative (apoptotic) cells. Furthermore, as depicted in Fig. 2B, the rate of necrosis was significantly increased in the DXR-treated group when compared with that in the untreated group $(\mathrm{P}<0.01,39.2$ vs. 6.5\%). This result demonstrated that DXR induced cell necrosis in human osteosarcoma cancer cells.

DXR reduces the viability of human osteosarcoma cells. The MG63 and U2OS cells were treated with increasing concentrations of DXR $(0,12.5,25,50,100,200,400,800$, $1,600,3,200,6,400$ and $12,800 \mathrm{ng} / \mathrm{ml}$ ) for $24 \mathrm{~h}$ and cell viability was determined by MTT assay. As depicted in Fig. 3, the half IC50 values of DXR in the MG63 and U2OS cells were 496.9 and $424.6 \mathrm{ng} / \mathrm{ml}$, respectively.

$D X R$ reduces the viability of osteosarcoma cells in apparent dose- and time-dependent manners. MG63 and U2OS cells were treated with increasing concentrations of DXR $(0,0.1$, 0.5 or $1.0 \mu \mathrm{g} / \mathrm{ml}$ ) for $24 \mathrm{~h}$ and cell viability was determined by MTT assay. MG63 cells and U2OS cells grew well and the number of passages was $<8$, and so they were selected for this experiment. As depicted in Fig. 4A and B, the viability of each cell line was significantly decreased between 0.5 and $1.0 \mu \mathrm{g} / \mathrm{ml}$, relative to the untreated cells in each group $(\mathrm{P}<0.01)$, in an apparent dose-dependent manner. Subsequently, the MG63 and U2OS cells were treated with 0.1 or $0.5 \mu \mathrm{g} / \mathrm{ml}$ DXR for 24, 48 and $72 \mathrm{~h}$, respectively. The data from this time-course 
A

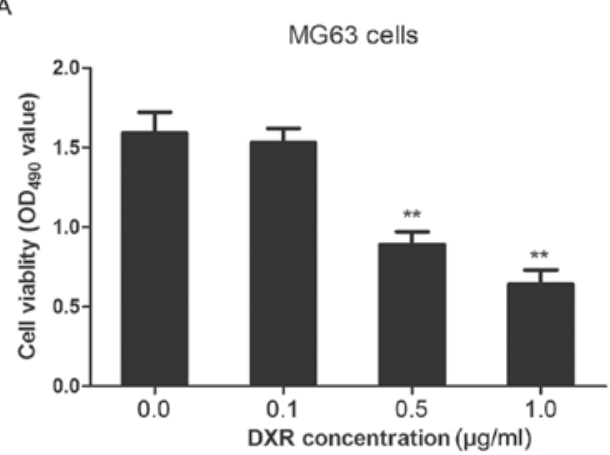

C

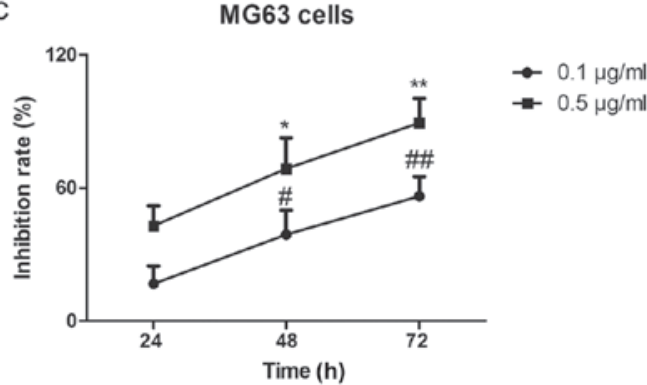

B

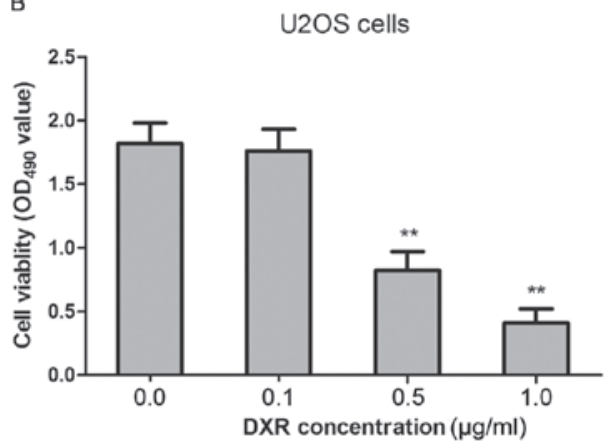

D

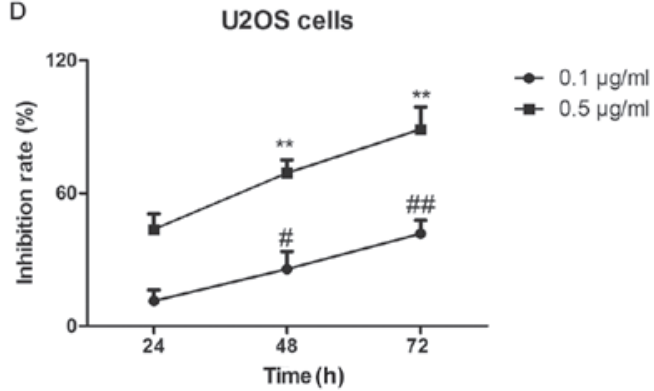

Figure 4. DXR promotes cell death in osteosarcoma cells in apparent dose- and time-dependent manners. (A) MG63 and (B) U2OS cells were treated with different concentrations of DXR $(0.1,0.5$ and $1.0 \mu \mathrm{g} / \mathrm{ml})$ for $24 \mathrm{~h}$, and cell viability was determined by MTT assay; the OD $\mathrm{O}_{400}$ values were depicted in a histogram. ${ }^{* *} \mathrm{P}<0.01 \mathrm{vs} .0 \mu \mathrm{g} / \mathrm{ml}$ DXR group ( $0.1 \%$ dimethyl sulfoxide-treated cells). Cell viability was also determined by MTT assay in (C) MG63 and (D) U2OS cells following temporal and dose treatment regimens with DXR. DXR concentrations of 0.1 and $0.5 \mu \mathrm{g} / \mathrm{ml}$ over time-courses of 24,48 and $72 \mathrm{~h}$, respectively, were administered. ${ }^{*} \mathrm{P}<0.05$ and $^{* *} \mathrm{P}<0.01$ vs. $24 \mathrm{~h}$ data of $0.5 \mu \mathrm{g} / \mathrm{ml}$ DXR group. ${ }^{*} \mathrm{P}<0.05$ and ${ }^{\# \#} \mathrm{P}<0.01 \mathrm{vs} .24 \mathrm{~h}$ data of $0.1 \mu \mathrm{g} / \mathrm{ml} \mathrm{DXR}$ group. DXR, doxorubicin; OD, optical density.

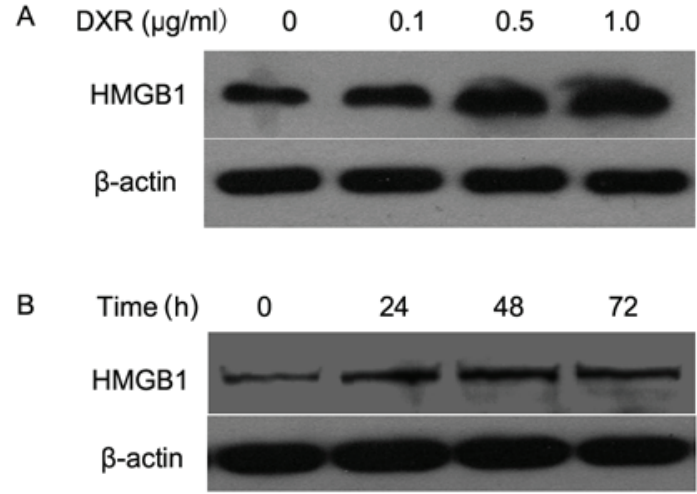

Figure 5. DXR treatment increases the levels of HMGB1 in osteosarcoma cells. (A) MG63 cells were treated with $0.1,0.5$ or $1.0 \mu \mathrm{g} / \mathrm{ml}$ DXR for $24 \mathrm{~h}$, and the expression of HMGB1 was detected by western blot analysis. (B) MG63 cells were treated with $0.5 \mu \mathrm{g} / \mathrm{ml}$ DXR for 24,48 and $72 \mathrm{~h}$, and HMGB1 expression was again evaluated by western blotting. $\beta$-actin was used as an internal reference gene. DXR, doxorubicin; HMGB1, high-mobility group protein 1.

assay indicated that DXR inhibited cell proliferation in a time-dependent manner (Fig. 4C and D). Notably, for each cell line, the inhibition rates were significantly higher at 48 and $72 \mathrm{~h}$ compared with that at $24 \mathrm{~h}(\mathrm{P}<0.05)$ following treatment with DXR (0.1 and $0.5 \mu \mathrm{g} / \mathrm{ml})$.

DXR treatment increases the levels of HMGB1 in osteosarcoma cells. To determine whether DXR treatment affected the production of DXR in osteosarcoma cells, MG63 cells were treated with $0.1,0.5$ and $1.0 \mu \mathrm{g} / \mathrm{ml}$ of DXR for $24 \mathrm{~h}$,
A MG63 cells
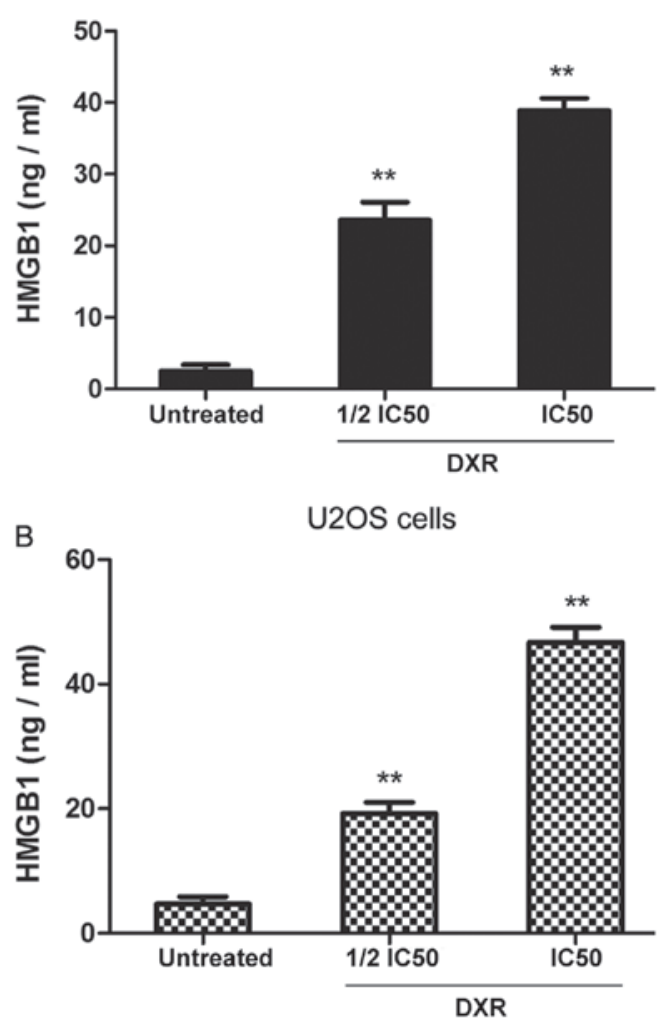

Figure 6. DXR treatment increases the secretion of HMGB1 from MG63 and U2OS cells. (A) MG63 and (B) U2OS cells were treated with DXR at $1 / 2 \mathrm{IC}_{50}$ and $\mathrm{IC}_{50}$ for $48 \mathrm{~h}$. The supernatant levels of HMGB1 were determined by ELISA. " $\mathrm{P}<0.01$ vs. untreated cells. DXR, doxorubicin; HMGB1, high-mobility group protein $1 ; \mathrm{IC}_{50}$, half maximal inhibitory concentration. 
and the expression of HMGB1 was assessed by western blot analysis. As depicted in Fig. 5A, the level of HMGB1 was gradually upregulated as the concentration of DXR increased. Subsequently, $0.5 \mu \mathrm{g} / \mathrm{ml}$ of DXR was used to treat MG63 cells for 24, 48 and $72 \mathrm{~h}$, and western blotting was repeated. The results indicated that HMGB1 expression was increased at $24 \mathrm{~h}$ and reached a maximum by $48 \mathrm{~h}$ when compared with that at $0 \mathrm{~h}$ (Fig. 5B). These data suggested that the level of HMGB1 was gradually increased by DXR treatment in dose- and time-dependent manners in the human osteosarcoma cells.

$D X R$ treatment increases the secretion of $H M G B 1$ from MG63 and U2OS cells. Furthermore, the presence of HMGB1 was determined in the culture media of MG63 and U2OS cells treated with two different concentrations of DXR ( $1 / 2$ IC50 and IC50 of each cell line) by ELISA. As depicted in Fig. 6, DXR increased the levels of HMGB1 in the culture media of MG63 and U2OS cells in an apparent dose-dependent manner when compared with untreated cells in each group $(\mathrm{P}<0.01)$. Therefore, the results demonstrated that the necrosis inducer DXR significantly increased the expression and secretion of HMGB1 in the human osteosarcoma cells.

\section{Discussion}

Chemotherapy is a critical treatment for patients with osteosarcoma (24-26). However, conventional chemotherapeutic agents not only elicit cell apoptosis, but also induce cell necrosis (27). Song et al (10) reported that following chemotherapy, the rate of tumor cell necrosis in control group tumors was increased by approximately $50 \%$, regardless of tumor volume and location. However, Li et al (11) investigated whether tumor necrosis was associated with DFS and overall survival rates of patients with osteosarcoma and observed no survival advantage at a tumor necrosis rate of $90 \%$. Thus, in the present study, the underlying molecular mechanism of cell necrosis and its potential effects on the proliferation and/or progression of osteosarcoma cells were investigated.

The levels of HMGB1 in human osteosarcoma cells were firstly detected, and the results demonstrated that HMGB1 expression was markedly increased in the MG63, SaoS-2 and U2OS osteosarcoma cell lines when compared with control HSkMCs. Subsequently, to simulate the cell/tissue necrosis associated with chemotherapy in osteosarcoma, the necrosis inducer DXR was administered to the MG63 and U2OS cells. The osteosarcoma cells were treated with increasing concentrations of DXR, and the results demonstrated that DXR effectively induced cell death in the osteosarcoma cell lines. Notably, the DXR-induced cell death was identified to be mainly of the cell necrosis type, which was determined by FACS analysis. The osteosarcoma MG63 cells were further treated with different concentrations of DXR for 24-72 h. It was observed that the levels of HMGB1 were gradually increased with increasing concentrations of DXR, and that the levels of HMGB1 were upregulated in an apparent time-dependent manner.

IC50 is typically used to measure the efficacy of a drug (28). In the present study, the IC50 values of DXR in the MG63 and U2OS cells were 496.9 and $424.6 \mathrm{ng} / \mathrm{ml}$, respectively.
This was consistent with Rajkumar (29), who reported that the osteosarcoma cell line 143B had an IC50 of $0.4 \mu \mathrm{mol} / 1$, while in a doxorubicin drug-resistant osteosarcoma cell line (143B-DR-DOX), the IC50 was $75 \mu \mathrm{moll} / 1$. Drug resistance remains a challenge for clinical therapy in human cancers, including osteosarcoma $(30,31)$. Future research should investigate the effects of combined therapy with necrosis inducer or apoptosis inducer on the proliferation of osteosarcoma cell lines.

In conclusion, the present study addressed the hypothesis that HMGB1 contributes to the development of chemoresistance in osteosarcoma. From the current findings, it may be speculated that necrotic osteosarcoma cancer cells produce and secrete HMGB1, which has previously been indicated to serve an important role as a tumor inducer that promotes the survival and proliferation of osteosarcoma cells. The present results may provide novel insights for improving the clinical treatment of human osteosarcomas.

\section{Acknowledgements}

The present study was supported by the National Natural Science Foundation of China (grant no. 81272015) and the Heilongjiang Provincial Department of Education Fund (grant no. 12541394).

\section{References}

1. Nthumba PM: Osteosarcoma of the jaws: A review of literature and a case report on synchronous multicentric osteosarcomas. World J Surg Oncol 10: 240, 2012.

2. Bertucci F, Araujo J and Giovannini M: Pancreatic metastasis from osteosarcoma and Ewing sarcoma: Literature review. Scand J Gastroenterol 48: 4-8, 2013.

3. Fayda M, Kebudi R, Dizdar Y, Gorgun O, Gun F, Aksu G and Ayan I: Spontaneous pneumothorax in children with osteosarcoma: Report of three cases and review of the literature. Acta Chir Belg 112: 378-381, 2012.

4. He H, Ni J and Huang J: Molecular mechanisms of chemoresistance in osteosarcoma (Review). Oncol Lett 7: 1352-1362, 2014.

5. Haddox CL, Han G, Anijar L, Binitie O, Letson GD, Bui MM and Reed DR: Osteosarcoma in pediatric patients and young adults: A single institution retrospective review of presentation, therapy, and outcome. Sarcoma 2014: 402509, 2014.

6. PosthumaDeBoer J, Witlox MA, Kaspers GJ and van Royen BJ: Molecular alterations as target for therapy in metastatic osteosarcoma: A review of literature. Clin Exp Metastasis 28: 493-503, 2011.

7. Springfield DS, Schakel ME Jr and Spanier SS: Spontaneous necrosis in osteosarcoma. Clin Orthop Relat Res: 233-237, 1991.

8. He JP, Hao Y, Wang XL, Yang XJ, Shao JF, Guo FJ and Feng JX: Review of the molecular pathogenesis of osteosarcoma. Asian Pac J Cancer Prev 15: 5967-5976, 2014.

9. Sami SH, Rafati AH and Hodjat P: Tissue necrosis after chemotherapy in osteosarcoma as the important prognostic factor. Saudi Med J 29: 1124-1129, 2008.

10. Song WS, Jeon DG, Cho WH, Kong CB, Cho SH, Lee SY and Lee SY: Spontaneous necrosis and additional tumor necrosis induced by preoperative chemotherapy for osteosarcoma: A case-control study. J Orthop Sci 20: 174-179, 2015.

11. Li X, Ashana AO, Moretti VM and Lackman RD: The relation of tumour necrosis and survival in patients with osteosarcoma. Int Orthop 35: 1847-1853, 2011.

12. Kato H, Wakabayashi H, Naito $Y$, Kato S, Nakagawa T, Matsumine A and Sudo A: Anti-tumor necrosis factor therapy inhibits lung metastasis in an osteosarcoma cell line. Oncol 88: 139-146, 2015.

13. Gorlick R and Meyers PA: Osteosarcoma necrosis following chemotherapy: Innate biology versus treatment-specific. J Pediatr Hematol Oncol 25: 840-841, 2003. 
14. Martinotti S, Patrone M, Manfredi M, Gosetti F, Pedrazzi M, Marengo E and Ranzato E: HMGB1 osteo-modulatory action on osteosarcoma SaOS-2 cell line: An integrated study from biochemical and -Omics approaches. J Cell Biochem 117: 2559-2569, 2016.

15. Huang J, Ni J, Liu K, Yu Y, Xie M, Kang R, Vernon P, Cao L and Tang D: HMGB1 promotes drug resistance in osteosarcoma. Cancer Res 72: 230-238, 2012.

16. Wu T, Zhang W, Yang G, Li H, Chen Q, Song R and Zhao L: HMGB1 overexpression as a prognostic factor for survival in cancer: A meta-analysis and systematic review. Oncotarget 7 : 50417-50427, 2016.

17. Li X, Wang S, Chen Y, Liu G and Yang X: miR-22 targets the 3'UTR of HMGB1 and inhibits the HMGB1-associated autophagy in osteosarcoma cells during chemotherapy. Tumour Biol 35: 6021-6028, 2014

18. Wang Z, Wang X, Li J, Yang C, Xing Z, Chen R and Xu F: HMGB1 knockdown effectively inhibits the progression of rectal cancer by suppressing HMGB1 expression and promoting apoptosis of rectal cancer cells. Mol Med Rep 14: 1026-1032, 2016.

19. Xia Q, Xu J, Chen H, Gao Y, Gong F, Hu Land Yang L: Association between an elevated level of HMGB1 and non-small-cell lung cancer: A meta-analysis and literature review. OncoTargets Ther 9: 3917-3923, 2016.

20. Meng Q, Zhao J, Liu H, Zhou G, Zhang W, Xu X and Zheng M: HMGB1 promotes cellular proliferation and invasion, suppresses cellular apoptosis in osteosarcoma. Tumour Biol 35: 12265-12274, 2014.

21. Aykul S and Martinez-Hackert E: Determination of half-maximal inhibitory concentration using biosensor-based protein interaction analysis. Anal Biochem 508: 97-103, 2016.

22. Xia J, Yu X, Song X, Li G, Mao X and Zhang Y: Inhibiting the cytoplasmic location of HMGB1 reverses cisplatin resistance in human cervical cancer cells. Mol Med Rep 15: 488-494, 2017.

23. Rem AI, Oosterhuis JA, Korver JG and van den Berg TJ Transscleral laser thermotherapy of hamster Greene melanoma: Inducing tumour necrosis without scleral damage. Melanoma Res 11: 503-509, 2001.
24. Uhl M, Saueressig U, van Buiren M, Kontny U, Niemeyer C, Köhler G, Ilyasov K and Langer M: Osteosarcoma: Preliminary results of in vivo assessment of tumor necrosis after chemotherapy with diffusion- and perfusion-weighted magnetic resonance imaging. Invest Radiol 41: 618-623, 2006.

25. Samimi MA, Mirkheshti N and Pazouki A: Assessing the percent of necrosis after neoadjuvant chemotherapy with $24 \mathrm{~h}$ infusional cisplatin/3 days Doxorubicin intermittent with Ifosfamide-Doxorubicin for osteosarcoma. Int J Hematol Oncol Stem Cell Res 8: 5-8, 2014

26. Cui Q, Li D, Liu C, Guo J, Liu S, Liu Y, Wang X and Zeng Y: The significance of MGMT protein detection in evaluation of osteosarcoma necrosis rate after cisplatin chemotherapy. Bos J Basic Med Sci 11: 80-83, 2011.

27. Bajpai J, Gamnagatti S, Kumar R, Sreenivas V, Sharma MC, Khan SA, Rastogi S, Malhotra A, Safaya R and Bakhshi S: Role of MRI in osteosarcoma for evaluation and prediction of chemotherapy response: Correlation with histological necrosis. Ped Radiol 41: 441-450, 2011.

28. Blanchard N, Richert L, Coassolo P and Lave T: Qualitative and quantitative assessment of drug-drug interaction potential in man, based on Ki, IC50 and inhibitor concentration. Curr Drug Metab 5: 147-156, 2004.

29. Rajkumar T and Yamuna M: Multiple pathways are involved in drug resistance to doxorubicin in an osteosarcoma cell line. Anticancer Drugs 19: 257-265, 2008

30. Wan Y, Xu L, Zhuo N, Ge J, Chen G and Lu XB: The clinical significance of neoadjuvant chemotherapy in improving the drug resistance of osteosarcoma. Minerva Med 108: 479-481, 2017.

31. Wang Y and Teng JS: Increased multi-drug resistance and reduced apoptosis in osteosarcoma side population cells are crucial factors for tumor recurrence. Exp Ther Med 12: 81-86, 2016. 